\title{
USAHA MINUMAN TRADISIONAL WEDANG SEGAR DI KABUPATEN MADIUN
}

\author{
Onny Purnamayudhia ${ }^{1}$, Bachtiar Rahman Halik ${ }^{2}$, Ampar Jaya Suwondo ${ }^{3}$ \\ ${ }^{1}$ Universitas Wijaya Putra, Fakultas Teknik, Program Studi Teknik Industri, Surabaya, Indonesia \\ ${ }^{2}$ Universitas Wijaya Putra, Fakultas Ekonomi \& Bisnis, Program Studi Akuntansi, Surabaya, Indonesia \\ ${ }^{3}$ Universitas Wijaya Putra, Fakultas Teknik, Program Studi Teknik Industri, Surabaya, Indonesia \\ onnyyudhia14@gmail.com¹, bachtiar@uwp.ac.id², amparj@yahoo.co.id ${ }^{3}$
}

Submited : 31 July 2020

Acepted : 26 Agustus 2020

Published : Desember 2020

\begin{abstract}
Abstrak
Program Kemitraan Masyarakat merupakan suatu program yang bertujuan untuk memberikan pelatihan dan pendampingan bagi Mitra UKM, baik itu manajemen produksi, manajemen keuangan, dan manajemen pemasaran. Setelah dilakukan survey, maka, tim pelaksana Pengabdian Kepada Masyarakat menjalin kerjasama dengan mitra UKM usaha minuman tradisional wedang segar di Kabupaten Madiun. Permasalahan yang dihadapi mitra UKM selama ini adalah hasil produksi yang belum ada peningkatan dan hanya mampu memenuhi kebutuhan konsumen pada segmen pasar terbatas. Hal ini disebabkan karena proses pengolahan produk minuman tradisional wedang segar masih menggunakan peralatan manual. Seiring dengan semakin banyaknya permintaan konsumen terhadap produk minuman wedang segar, tim pelaksana pengabdian masyarakat menawarkan solusi kepada mitra UKM agar produk diolah dengan menggunakan mesin otomatis yang berbasis Teknologi Tepat Guna (TTG), agar produksi bisa berjalan lebih cepat dan hasil produksi lebih banyak. Hasil dari pengabdian masyarakat ini mampu memberikan solusi yang bermanfaat bagi mitra UKM, yaitu dengan menggunakan mesin Teknologi Tepat Guna (TTG) mampu memproduksi sebanyak 23.275 bungkus selama sebulan, sistem pencatatan administrasi dan keuangan yang rapi, dan pemasaran yang menggunakan Sistem Bauran Pemasaran serta adanya inovasi dalam hal kemasan produk. Sehingga, target penjualan dapat tercapai dan pemasaran produk dapat menjangkau seluruh wilayah kabupaten dan kota madiun, bahkan hingga luar kota.
\end{abstract}

Kata Kunci : UKM, Teknologi Tepat Guna (TTG), Wedang Segar, Produksi, Keuangan 


\section{PENDAHULUAN}

Indonesia adalah negara tropis yang kaya akan bahan rempah-rempah tanaman/tumbuhtumbuhan yang dapat digunakan sebagai bahan obat herbal. Salah satunya yang sudah diwariskan oleh para leluhur, yaitu jamu tradisional. Begitu banyak bahan dari tumbuh-tumbuhan yang bisa diolah menjadi bahan jamu baik dalam bentuk bahan baku maupun olahan serbuk/bubuk.

Seperti yang terjadi saat ini, wabah virus corona telah menyerang seluruh dunia, tentu membutuhkan obat yang mampu meningkatkan stamina tubuh seseorang. Hal inilah yang akhirnya menginspirasi masyarakat Indonesia untuk kembali mengonsumsi minuman tradisional herbal.

Perkembangan saat ini, minum jamu tradisional sudah menjadi tradisi yang telah diminati oleh semua kalangan baik tua maupun muda. Oleh karena itu, tim pengabdian kepada masyarakat mencoba memberikan solusi dengan menciptakan teknologi tepat guna (TTG) yang nantinya mampu memproduksi bahan jamu dari bahan baku diubah menjadi serbuk/bubuk jamu yang siap untuk diminum dalam bentuk minuman wedang segar.

Tim pengabdian masyarakat menjalin kerjasama dengan mitra UKM. minuman tradisionalwedang segardi Kabupaten Madiun, tepatnya di desa Nglandung, Kecamatan Geger. Jumlah mitra UKM yang diajak untuk bekerjasama dalam pengembangan usaha ini adalah 1 (satu) orang. Nama Mitra UKM yaitu Ibu Endang Kartikaningsih. berikut, koordinasi dengan Mitra UKM :

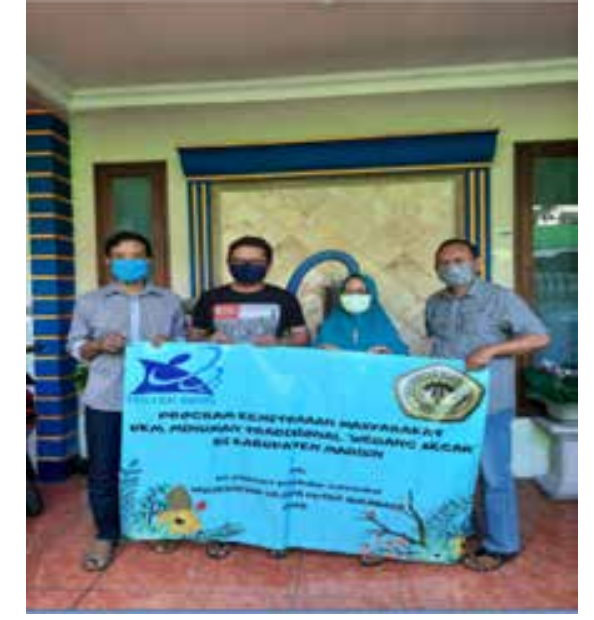

Gambar 1. Koordinasi dengan Mitra UKM

Usaha dari Mitra UKM. Yang sudah berjalan selama ini, dalam memproduksi minuman tradisional wedang segar ini masih bersifat manual. Selain itu, produk yang dipasarkan atas dasar pesanan konsumen dan ditempatkan pada toko/warung/cafe yang buka usaha penjualan produk lain. Jumlah produk minuman tradisional wedang segar maksimal 15.125 bungkus per bulan. Bahan minuman tradisional wedang segar yang digunakan antara lain bahan utama yang terdiri dari secang, kapulaga, kunyit kuning, kunyit putih, jahe merah, jahe putih, cengkeh, jati china, daun salam, daun pandan, daun jeruk purut, kulit jeruk purut, temulawak, gula batu, serei, kayu manis, kencur dan asam jawa. Proses pembuatan minuman tradisional wedang segar yang selama ini dilakukan oleh mitra UKM adalah sebagai berikut : a) masing-masing bahan dicuci hingga bersih, dicuci berulang-ulang; b) masing-masing bahan dijemur dibawah sinar matahari hingga benar-benar kering; c) masing-masing bahan diiris/dipotong kecil-kecil, kecuali daun salam, secang, kapulaga, cengkeh, daun jeruk purut, gula batu, daun jati china; d) setelah semua 
bahan diiris (kecuali daun salam, secang, kapulaga, cengkeh, daun jeruk purut, gula batu, daun jati china) dijemur di atas tampah di bawah matahari langsung hingga benar-benar kering; e) langkah berikutnya semua bahan ditimbang dan dimasukkan di dalam kantong plastik.

Permasalahan yang dihadapi oleh mitra UKM adalah keterbatasan modal kerja, pengelolaan manajemen usaha yang terbatas khususnya dalam hal produksi, dan jangkauan pemasaran yang belum terlalu luas, karena minimnya tenaga pemasaran, serta manajemen mutu yang belum bagus.

\section{TINJAUAN PUSTAKA}

Kajian pustaka yang mendasari dalam pelaksanaan pengabdian masyarakat ini mencakup tiga aspek yaitu manajemen produksi, manajemen keuangan, dan manajemen pemasaran.

\section{Manajemen Produksi}

Manajemen produksi tidak terlepas dari pengertian manajemen. Dengan istilah manajemen dimaksudkan adalah kegiatan atau usaha yang dilakukan untuk mencapai suatu tujuan dengan menggunakan atau mengorganisasikan kegiatan-kegiatan orang lain. Pengertian manajemen produksi menurut Sofjan Assauri (2008:12) menyatakan bahwa "Manajemen Produksi dan Operasi yaitu kegiatan yang mengatur dan mengkoordinasikan penggunaan sumber-sumber daya yang berupa sumber daya manusia, sumber daya alat dan sumber daya dana serta bahan secara efektif dan efisien untuk menciptakan dan menambah kegunaan (utility) sesuatu barang atau jasa".

Ruang lingkup manajemen produksi akan mencakup perancangan atau penyiapan sistem produksi dan operasi serta pengoperasian dari sistem produksi dan operasi. Pembahasan dalam perancangan atau desain dari sistem produksi dan operasi menurut Sofjan Assauri (2008:27), ruang lingkup manajemen produksi meliputi:

a) Seleksi dan rancangan atau desain hasil produksi (product)

b) Seleksi dan perancangan proses dan peralatan

c) Pemilihan lokasi dan site perusahaan dan unit produk

d) Rancangan tugas perusahaan

e) Strategi produksi dan operasi serta pemilihan kapasitas

\section{Manajemen Keuangan}

Sasaran finansial unit usaha ditujukan pada pencarian, penemuan yang fungsional dan pengumpulan informasi tentang posisi finansial dalam satuan unit usaha atau bidang fungsional yang terdapat dalam lingkungan unit usaha. Dua pertimbangan mengapa hal ini penting, antara lain :

a) Untukmenjamin bahwa posisi keuangan dalam satuan kerja atau bidang fungsional memperkuat posisi finansial unit usaha sebagai keseluruhan.

b) Guna menjamin ketaatan kebijakan finansial yang telah ditetapkan termasuk kebijakan yang menyangkut pengendalian dibidang keuangan.

Sebagai alat ukur untuk mengetahui efisiensi dan efektifitas pengelolaan keuangan unit usaha, diaplikasikan dalam bentuk Laporan Keuangan yang berupa Laporan Sumber dan Penggunaan Dana (Laporan Arus Kas), Laporan Laba/Rugi dan Laporan Posisi Keuangan (Neraca) dalam satu periode tertentu (Agus Sartono, 2013). 


\section{Manajemen Pemasaran}

Aspek Penjualan dan Pemasaran memliki tujuan strategis antara lain

Tujuan strategis fungsi penjualan dan pemasaran antara lain dalam sub bab berikut ini.

\section{Tujuan Strategis Penjualan}

Strategi penjualan produk yang dilakukan meliputi:

a) Melakukan program administrasi penjualan untuk mendukung strategi penjualan dan pemasaran jangka pendek maupun jangka panjang.

b) Menyusun forecast/rencana penjualan produk.

c) Menjalankan fungsi pelayanan purna jual secara efektif kepada pelanggan

\section{Tujuan Strategi Pemasaran}

Strategi pemasaran yang diperlukan antara lain :

a) Melakukan analisa pasar yang berkaitan dengan selera konsumen dan perilaku konsumen secara berkelanjutan.

b) Menyusun strategi baru secara khusus untuk kemungkinan pembuatan produk baru.

c) Membuat strategi pemasaran untuk mendukung proyeksi penjualan jangka panjang maupun jangka pendek (Agustina Shinta, 2011).

\section{METODE}

Implementasi pelaksanaan pengabdian masyarakat ini, diterapkan beberapa metode yang bertujuan untuk membantu usaha mitra UKM. Metode tersebut antara lain : Produksi: a) pembuatan mesin produksi minuman tradisional wedang segar yang tepat guna dan otomatis; b) pelatihan dan pendampingan pengoperasian mesin; c) evaluasi hasil pemakaian peralatan dan mesin teknologi tepat guna. Pemasaran: a) pelatihan dan pendampingan memilih pasar potensial serta menerima pesanan pelanggan; $b$ ) pelatihan strategi segmentasi, targeting, positioning pasar dan promosi; c) Pembuatan label/merek dan kemasan yang menarik; d) evaluasi hasil pasar potensial serta evaluasi strategi segmentasi, targetting, positioning pasar dan promosi. Kewirausahaan/Inovasi: a). Pelatihan dan pendampingan dalam pembuatan produk yang bercita rasa; b) evaluasi hasil cita rasa wedang segar. Manajemen Keuangan: a) pelatihan dan pendampingan penerapan metode penentuan biaya produksi atas penggunaan mesin TTG berdasarkan aktivitas produksi (activity based costing); b) pelatihan dan pendampingan penerapan pencatatan administrasi dan laporan keuangan secara tertib; c) evaluasi hasil penerapan metode activity based costing serta pencatatan laporan keuangan.

\section{HASIL DAN PEMBAHASAN}

Pelaksanaan pengabdian masyarakat ini dilaksanakanselamakuranglebih6(enam)bulan. Dari hasil evaluasi pengabdian masyarakat, tim pengabdian mampu memberikan kontribusi yang berkelanjutan bagi pengembangan usaha mitra UKM minuman tradisional wedang segar.

Selama kegiatan pengabdian masyarakat, tim telah memberikan manfaat bagi mitra UKM. Melalui beberapa tahapan, antara lain :

\section{Bidang Produksi}

Tim Pengabdian Masyarakat berhasil menciptakan Sebuah Mesin Teknologi Tepat Guna (TTG) bagi mitra UKM yang mampu memproduksi dengan jumlah produk lebih banyak daripada produksi semula yang bersifat 
manual. Dengan Mesin ini, produk olahan bahan baku untuk minuman tradisional wedang segar dapat diubah menjadi bubuk/serbuk yang siap diseduh.

Tahapan proses produksi olahan bahan baku minuman tradisional wedang segar diawali dengan melakukan pemilihan bahan sebanyak 18 item.

Kebutuhan bahan baku yang diperlukan dan dipersiapkan mitra UKM adalah bahan baku untuk produksi saat ini dan tambahan pengadaan untuk cadangan proses produksi periode berikutnya (safety stock), sehingga proses produksi bisa berjalan tanpa terputus setiap saat.

Hal ini dilakukan karena kontur masingmasing jenis bahan bakunya tidak sama dan memerlukan proses pengeringan (disemai) dalam waktu 3 atau 4 hari bahkan satu minggu untuk bahan baku yang basah/lembab. Proses pengeringan melalui sinar matahari (tidak menggunakan mesin oven) dengan pertimbangan bahwa :

a) Bahan baku yang diproduksi harus dalam keadaan kering higienis;

b) Bahan baku yang dipersiapkan beberapa di antaranya dalam keadaan setengah basah sehingga sulit untuk digiling; c) Pengadaan tambahan cadangan bahan baku yang dikeringkan pada musim kemarau harus bisa digunakan pada proses produksi selama musim penghujan berlangsung agar kebutuhan konsumen tetap terpenuhi.

Selain itu, tim pengabdian masyarakat juga memberikan pelatihan dan pendampingan dalam bidang produksi kepada Mitra UKM, antara lain :

a) Cara membuat Time Schedule pengadaan bahan baku dan perencanaan produksi.

b) Pelatihan pengoperasian mesin TTG dan perawatannya.

c) Teknik proses produksi

d) Sistem penyimpanan bahan baku dan produk jadi.

e) Teknik pengeringan bahan baku.

f) Teknik material handling

g) Teknik pembuatan minuman wedang segar siap saji.

Berikut ini foto-foto Pelaksanaan di bidang Produksi :

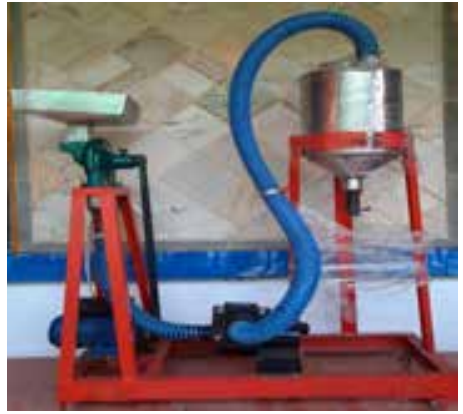

Gambar 2. Mesin Teknologi Tepat Guna (TTG)

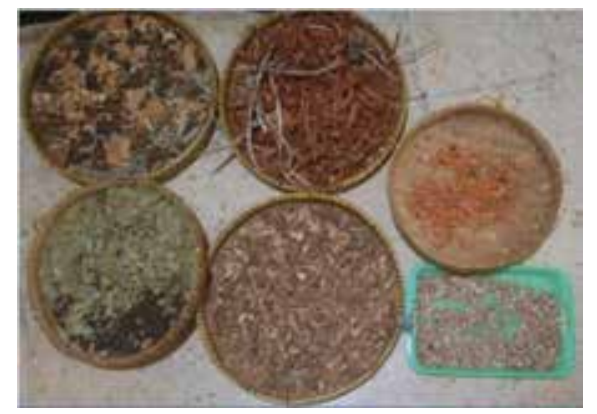

Gambar 3. Proses Pemilihan dan Pengeringan Bahan Wedang Segar 
HUMANISM Vol.1 No. 3 Desember 2020

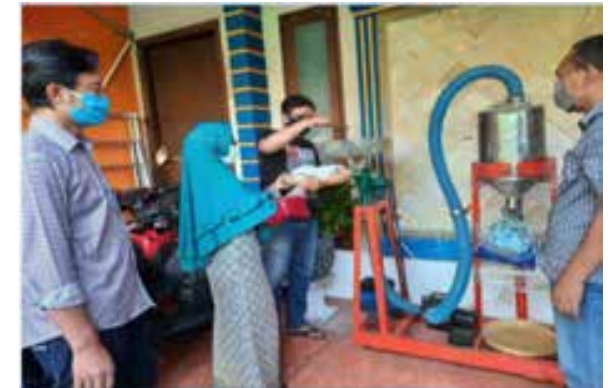

Gambar 4. Pelatihan Proses Produksi Wedang Segar

\section{Bidang Manajemen dan Administrasi Keuangan}

Sebagai alat ukur untuk mengetahui efisiensi dan efektifitas pengelolaan keuangan unit usaha, diaplikasikan dalam bentuk Laporan Keuangan yang berupa Laporan Sumber dan Penggunaan Dana (Laporan Arus Kas), Laporan Laba/Rugi, dan Laporan Posisi Keuangan (Neraca) dalam satu periode tertentu. Pada saat ini mitra UKM belum menerapkan Sistem Pencatatan Administrasi Keuangan dan Pembukuan dengan baik, di antaranya :

1. Semua pengeluaran bahan baku dan pembantu serta pengeluaran lain-lain hanya dicatat di dalam sebuah buku yang memuat semua pengeluaran yang dicatat menjadi satu, tanpa ada pengelompokan masing-masing jenis pengeluaran.

2. Biaya tenaga kerja belum dimasukkan ke dalam biaya produksi dan dicatat di dalam biaya administrasi \& umum (biaya operasional).

3. Perencanaan keuangan banyak didasarkan pada estimasi mitra saja, tanpa didukung data keuangan yang riil maupun data historis.

4. Mitra belum bisa menyusun laporan arus kas, laba/rugi, dan neraca.

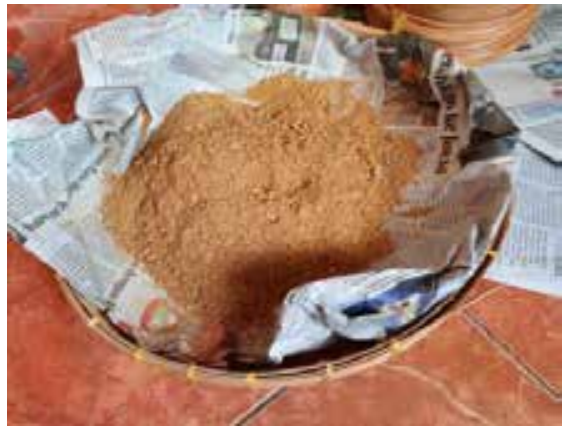

Gambar 5. Hasil Pengolahan Menggunakan Mesin TTG

Sehubungan dengan masalah yang dihadapi mitra tersebut di atas, maka tim pelaksana Pengabdian Kepada Masyarakat perlu memberikan pendampingan dan pelatihan dalam hal pengelolaan \& pengendalian keuangan serta sistem pelaporan pembukuannya, antara lain :

1. Penyusunan Laporan Arus Kas (Sumber dan Penggunaan Dana).

2. Penyusunan Laporan Laba/Rugi.

3. Penyusunan Laporan Posisi Keuangan atau Neraca.

\section{Laporan Harian Kas}

Berikut merupakan foto kegiatan pelaksanaan pengabdian masyarakat di bidang manajemen dan administrasi keuangan :

1) Pendampingan dan Pelatihan Manajemen dan Administrasi Keuangan

1) Laporan Kas (Sumber dan Penggunaan Dana), Hasil Pengoperasian 1 (satu) unit mesin pengolah, periode bulan Agustus 2020 


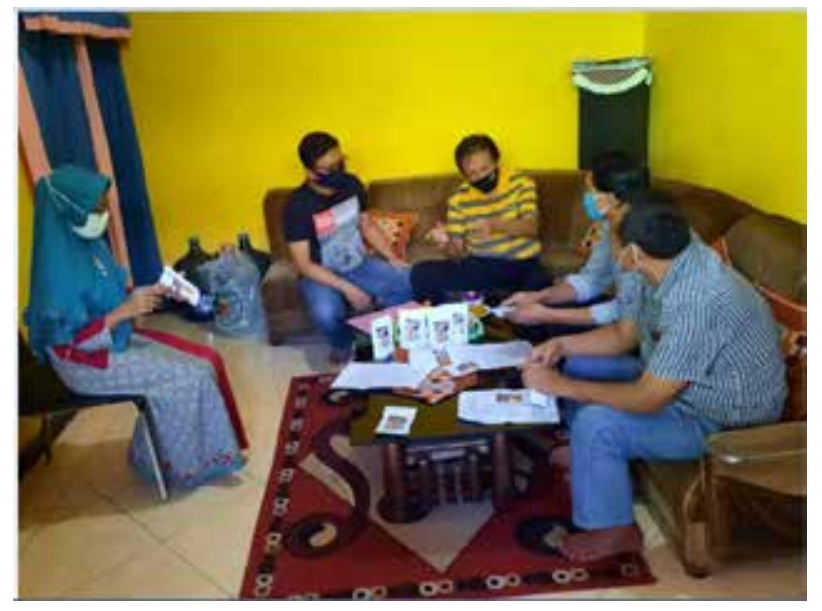

Gambar 6. Pendampingan dan Pelatihan Manajemen dan Administrasi Keuangan

Tabel 1. Laporan Kas

(Sumber dan Penggunaan Dana)

\begin{tabular}{|c|c|c|c|}
\hline No. & Uraian & Debet (Rp.) & Kredit (Rp.) \\
\hline \multirow{4}{*}{ II. } & \multirow{4}{*}{$\begin{array}{l}\text { Saldo Awal Per } 01 \text { Agustus } 2020 \\
\text { Penerimaan / Sumber Dana } \\
\text { - Modal kerja } \\
\text { - Penerimaan uang muka penjualan }\end{array}$} & 1.175 .000 & \\
\hline & & & \\
\hline & & 3.000 .000 & \\
\hline & & 1.000 .000 & \\
\hline \multirow[b]{3}{*}{ III. } & \multirow{3}{*}{$\begin{array}{l}\text { - Penerimaan Tagihan penjualan } \\
\text { - Hasil Penjualan Tunai } \\
\text { Jumlah Penerimaan/Sumber Dana } \\
\text { Jumlah Dana Yang Tersedia (I+II) }\end{array}$} & $\begin{array}{r}5.940 .000 \\
55.860 .000\end{array}$ & \\
\hline & & 65.800 .000 & \\
\hline & & 66.975 .000 & \\
\hline \multirow[t]{2}{*}{ IV. } & $\begin{array}{l}\text { Pengeluaran / Penggunaan Dana } \\
\text { - Pembelian bahan pokok } \\
\text { - Pembelian bahan pembantu }\end{array}$ & & $\begin{array}{l}15.727 .500 \\
25.327 .500\end{array}$ \\
\hline & - Upah tenaga kerja & & 6.000 .000 \\
\hline \multirow{4}{*}{ V. } & \multirow{4}{*}{$\begin{array}{l}\text { - Pemeliharaan peralatan/mesin } \\
\text { - Iuran/retribusi } \\
\text { - Biaya transportasi/parkir \& konsumsi } \\
\text { - BBM/Olie } \\
\text { - Biaya cetak label kemasan } \\
\text { - Biaya listrik pembangkit mesin } \\
\text { - Biaya alat tulis \& fotocopy } \\
\text { - Biaya pengiriman/angkutan } \\
\text { - Biaya operasional lain-lain } \\
\text { Jumlah Pengeluaran / Penggunaan } \\
\text { Dana } \\
\text { Saldo Akhir (III-IV) Per } 31 \text { Agustus } \\
2020\end{array}$} & & $\begin{array}{r}300.000 \\
87.000 \\
100.000 \\
78.000 \\
90.000 \\
175.000 \\
45.000 \\
5.000 .000 \\
200.000\end{array}$ \\
\hline & & & 53.130 .000 \\
\hline & & & 13.845 .000 \\
\hline & & 66.975 .000 & 66.975 .000 \\
\hline
\end{tabular}


HUMANISM Vol.1 No. 3 Desember 2020

Tabel 2. Laporan Neraca

Hasil Pengoperasian 1 (satu) Unit Mesin Produksi Untuk 1 (satu) Mitra

Per : 31 Agustus 2020

\begin{tabular}{|c|c|}
\hline & (Rp.) \\
\hline \multicolumn{2}{|l|}{ ASET } \\
\hline \multicolumn{2}{|l|}{ Aset Lancar } \\
\hline - Kas dan Setara Kas & 13.845 .000 \\
\hline - Piutang Usaha & 8.025 .000 \\
\hline - Persediaan bahan baku \& pembantu & 27.655 .000 \\
\hline - Uang muka pembelian & 945.000 \\
\hline Jumlah Aset Lancar & 50.470 .000 \\
\hline \multicolumn{2}{|l|}{ ASET TIDAK LANCAR } \\
\hline $\begin{array}{l}\text { - Aset tetap setelah dikurangi akumulasi penyusutan s/d. } 31 \text { Agustus } 2020 \\
\text { sebesar Rp. 525.000,- }\end{array}$ & 14.475 .000 \\
\hline Jumlah Aset Tidak Lancar & 14.475 .000 \\
\hline Total Aset & 64.945 .000 \\
\hline & (Rp.) \\
\hline \multicolumn{2}{|l|}{ Kewajiban dan Ekuitas } \\
\hline \multicolumn{2}{|l|}{ Kewajiban Lancar } \\
\hline - Uang muka pendapatan & 1.000 .000 \\
\hline Jumlah Kewajiban Lancar & 1.000 .000 \\
\hline \multicolumn{2}{|l|}{ Ekuitas } \\
\hline - Modal disetor & 3.000 .000 \\
\hline Modal penyertaan (aset mesin) & 15.000 .000 \\
\hline - Sisa Laba Tahun Lalu & 2.120 .000 \\
\hline - Sisa Laba Tahun Berjalan (Agustus 2020) & 43.825 .000 \\
\hline Jumlah Ekuitas & 63.945.000 \\
\hline Total Kewajiban dan Ekuitas & 64.945 .000 \\
\hline
\end{tabular}

Tabel 3. Laporan Laba / Rugi

Periode : $01 \mathrm{~s} /$ d. 31 Agustus 2020

\begin{tabular}{|l|l|r|}
\hline & & \multicolumn{1}{|c|}{ (Rp.) } \\
\hline I. & Pendapatan Usaha & 69.825 .000 \\
\hline & - Hasil Penjualan & - \\
\hline & -Potongan/Discount Penjualan & $\mathbf{6 9 . 8 2 5 . 0 0 0}$ \\
\hline & Hasil Penjualan Bersih & \\
\hline & & 4.300 .000 \\
\hline II. & Harga Pokok Penjualan & 9.100 .000 \\
\hline & - Pemakaian bahan pokok & 6.000 .000 \\
\hline & - Pemakaian bahan pembantu & 300.000 \\
\hline & - Tenaga kerja & 175.000 \\
\hline & - Pemeliharaan \& perbaikan alat produksi & \\
\hline & - Biaya produksi lain-lain/pemakaian listrik mesin & $\mathbf{1 9 . 8 7 5 . 0 0 0}$ \\
\hline & & $\mathbf{4 9 . 9 5 0 . 0 0 0}$ \\
\hline & Jumlah Harga Pokok Penjualan & \\
\hline & & \\
\hline III. & Laba Kotor Penjualan (I-II) & \\
\hline
\end{tabular}




\begin{tabular}{|l|l|r|}
\hline IV. & Beban Operasional & 87.000 \\
\hline & - Iuran/Retribusi & 100.000 \\
\hline & - Biaya Transportasi/Parkir \& konsumsi & 78.000 \\
\hline - BBM/Olie & 525.000 \\
\hline - Penyusutan mesin & 90.000 \\
\hline - Biaya pemasaran / cetak & 45.000 \\
\hline - Biaya Alat tulis \& fotocopy & 5.000 .000 \\
\hline & - Biaya pengiriman/angkutan & 200.000 \\
\hline & - Biaya operasional lain-lain & 6.125 .000 \\
\hline & Jumlah Beban Operasional & $\mathbf{4 3 . 8 2 5 . 0 0 0}$ \\
\hline V. & Laba Bersih & \\
\hline & & \\
\hline
\end{tabular}

\section{Bidang Pemasaran}

Penerapan Strategi Pemasaran yang dilakukan oleh Mitra UKM antara lain:

\section{Strategi Produk yang Dihasilkan}

Strategi produk yakni dengan menciptakan jenis minuman herbal higienis wedang segar yang memiliki cita rasa yang berbeda dengan produk lain yang sejenis dari kompetitor dalam bentuk pengolahan dari komponen bahan baku yang berbeda kwalitasnya.

\section{Strategi Harga Jual Produk}

Strategi ini meliputi penetapan harga jual produk yang terjangkau dengan mempertimbangkan kemampuan daya beli konsumen, karena dengan pencapaian harga jual secara tepat dan kompetitif akan mempengaruhi keberhasilan usaha dalam kegiatan pemasaran.

Dengan demikian strategi harga jual merupakan langkah yang harus benar-benar dipertimbangkan secara detail guna menarik minat konsumen.

\section{Strategi Pemilihan Lokasi/Wilayah Pemasaran}

Di dalam menentukan lokasi pemasaran, mitra UKM memilih lokasi di wilayah kabupaten dan kota Madiun, yang menurut hasil penelitian pasar, animo masyarakat pada produk herbal wedang segar di wilayah tersebut cukup besar dan sangat potensial untuk pengembangan produk baru.

\section{Strategi Promosi}

Dalam upaya promosi mitra UKM, menggunakan sistem marketing mix atau strategi bauran pemasaran yang terdiri dari beberapa variabel bauran produk, antara lain :

1. Tingkat kualitas produk

2. Ciri khas produk (aroma, rasa dan higienitas produk)

3. Bentuk dan merk produk

4. Pembungkus dan gambar/motif label serta tampilan kemasan produk

Penetapan harga jual dan pelayanan purna jual serta jaminan produk yang mengacu pada kualitas produk tergantung pada komposisi \& kualitas bahan baku serta tingkat kesulitan dalam proses produksinya. Selain kualitas produk, ciri khas produk, bentuk, dan merk produk serta pembungkus yang merupakan bauran produk, bisa meningkatkan volume penjualan dan menarik minat konsumen terhadap usaha Mitra UKM.

Salah satu strategi bauran pemasaran yang selama ini telah dilakukan mitra UKM adalah fungsi distribusi, yaitu saluran pemasaran atas produknya yang dapat tersalurkan kepada konsumen tepat sasaran melalui sistem pendistribusian secara langsung, baik secara door to door, atau ke toko-toko obat tradisional, toko penjual jamu herbal, kalangan instansi setempat secara efektif dan variatif sesuai 
HUMANISM Vol.1 No. 3 Desember 2020

target pasar dan dimungkinkan secara online dalam perkembangannya yang akan datang.

Berikut, foto kegiatan Pelaksanaan Pengabdian Masyarakat dengan Mitra UKM di bidang Pemasaran :

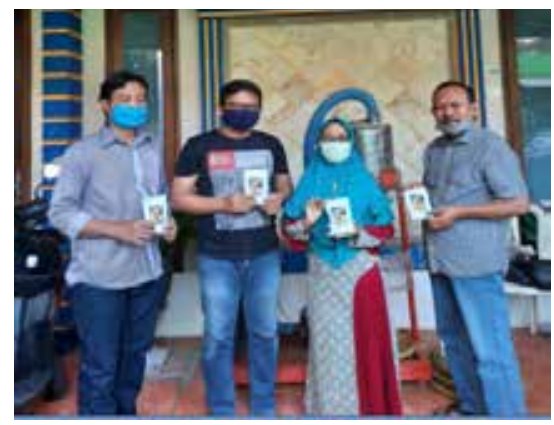

Gambar 7. Pendampingan dan Pelatihan Manajemen Pemasaran

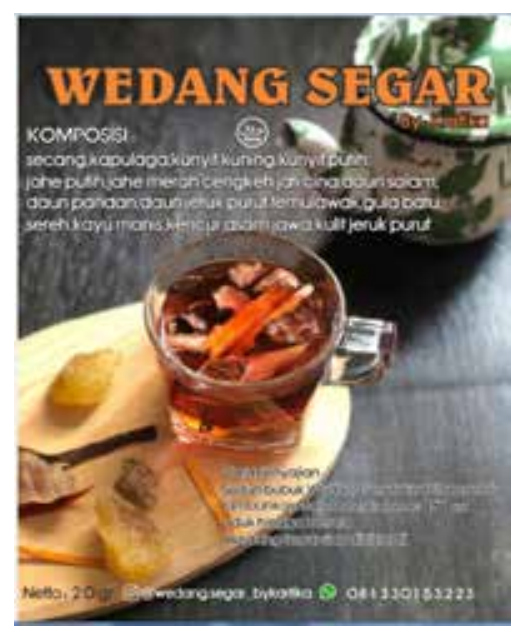

Gambar 8. Desain Label Kemasan Produk

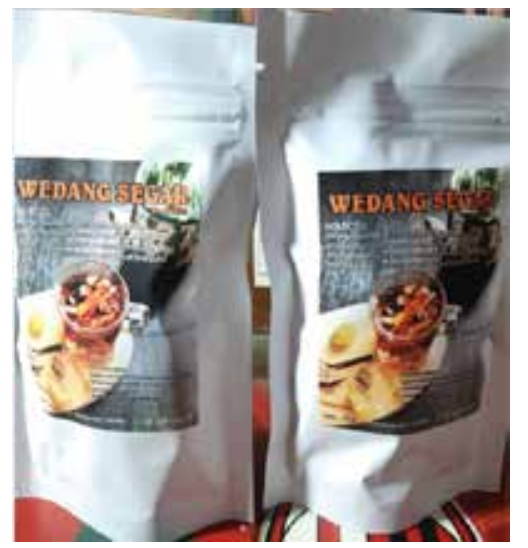

Gambar 9. Kemasan Produk Minuman Tradisional "Wedang Segar"

\section{KESIMPULAN}

Dari hasil pelaksanaan Pengabdian Kepada Masyarakat yang sudah dilakukan, dapat ditarik beberapa kesimpulan, yaitu :

1) Dengan adanya pemanfaatan mesin Teknologi Tepat Guna, jumlah produk yang dihasilkan mencapai 23.275 bungkus per bulan dan bisa memenuhi permintaan konsumen yang terus meningkat.

2) Dalam pencatatan administrasi dan manajemen keuangan, saat ini mitra UKM, sudah mampu mengelola dengan rapi, diantaranya menyusun laporan arus kas, laporan laba/rugi, laporan posisi keuangan atau neraca dan laporan harian kas.

3) Berdasarkan data keuangan selama bulan Agustus 2020, maka dengan adanya pemanfaatan mesin TTG, diperoleh data di antaranya: hasil penjualan produk sebesar Rp. 69.825.000,-; biaya produksi sebesar Rp. 19.875.000,; dan biaya operasional sebesar Rp. 6.125.000,-.

4) Dari segi pemasaran, ada perubahan dalam hal strategi pemasaran produk yang menerapkan stretegi bauran pemasaran serta adanya inovasi dalam hal mutu dan kemasan produk.

5) Dampak positif dari peningkatan target penjualan produk bagi Mitra UKM adalah meningkatnya pendapatan dan kesejahteraan mitra UKM, membuka lapangan kerja bagi warga desa sebagai tenaga produksi dan penjualan, dan berkontribusi menumbuhkan roda perekonomian di wilayah setempat. 


\section{DAFTAR PUSTAKA}

Sartono, Agus. (2013). Manajemen Keuangan

Teori dan Aplikasi (Edisi Keempat). BPFE Yogyakarta: BPPE.

Shinta, Agus. (2016). Manajemen Pemasaran.

Malang: Universitas Brawijaya Press (UB Press).

Assauri, Sofjan. (2008). Manajemen Produksi dan Operasi. Jakarta: Lembaga Penerbit Fakultas Ekonomi Universitas Indonesia. Mujanah, S., Maqsudi, A., \& Santoso, R. (2015). Peningkatan Kualitas Produk Melalui IbM Kelompok Usaha Kecil Jamu Tradisional di Kecamatan Sampang. JPM17: Jurnal Pengabdian Masyarakat, 1(02).

Murdiati. (1989). 200 Resep Jamu Jawa, Surabaya: CV. AMIN.

(2014). Javanesia, Sejarah

Tentang Jamu. http://Javanessia.com/ aboutjamu.htm

Latifah, S. W. (2017). Ibm Usaha Jamu Tradisional Pada Kelompok PKK Sekarpuro Kabupaten Malang. Studi Kasus Inovasi Ekonomi, 1(2). 